UDK: $330.322: 634.1 / .7$

POSLOVNA EKONOMIJA BUSINESS ECONOMICS

Godina XI

Originalni naučni rad

Broj 2

Str $43-54$

doi: $10.5937 /$ poseko12-15718

Ph.D Petar Gogic ${ }^{1}$, full professor

University of Belgrade, Faculty of Agriculture, Zemun

Ph.D Sanjin Ivanovic ${ }^{2}$, associate professor

University of Belgrade, Faculty of Agriculture, Zemun

\title{
ECONOMIC EFFECTIVENESS OF INVESTMENTS IN FRUIT TREE NURSERIES*
}

\begin{abstract}
In order to develop and improve fruit production in Serbia it is necessary to invest in establishment of nurseries for production of quality fruit seedlings. Therefore the goal of this paper is to analyze economic efficiency of investments in fruit nurseries. Discounting methods of investment evaluation (Net Present Value, Internal Rate of Return and Payback period) are used to determine profitability of investments in expected circumstances while sensitivity analysis and scenario analysis methods were used to evaluate investments in risky circumstances. It is determined that investments in fruit nurseries are economically efficient even in risky circumstances. Type of nurseries which provide more balanced cash flows is more economically efficient and less risky.
\end{abstract}

Key words: investments, nurseries, NPV, sensitivity analysis, scenario analysis

\footnotetext{
${ }^{1}$ petar.gogic@agrif.bg.ac.rs

2 sanjinivanovic@agrif.bg.ac.rs

* This paper is a result of the research projects No. 179028 - "Rural labor market and rural economy of Serbia - Income diversification as a tool to overcome rural poverty" financed by the Ministry of Education and Science of the Republic of Serbia.
} 


\section{INTRODUCTION}

There are very good natural conditions for fruit production in Serbia. Nevertheless, fruit production in Serbia has many negative characteristics, such as the extensive way of fruit production, presence of obsolete cultivars which produce low yields, mismatch between cultivars and needs of the processing industry as well as export needs, inefficient organization of production, small plots situated on family farms etc.

Although the area under orchards in Serbia in the recent years has stagnated, total fruit production has been increasing due to increased yield per tree. In the last two decades the areas under orchards in Serbia were stable and amounted to an average of about $163,500 \mathrm{ha}^{3}$, or about $4.70 \%$ of the total utilized agricultural area. It is a higher prevalence comparing to the world average, which is less than $3.40 \%$ of the total agricultural land ${ }^{4}$.

The use of quality fruit seedlings for establishment of orchards is of great importance for the stable production and the increase in the volume of fruit production. Production of fruit seedlings in organized nurseries in Serbia has begun to develop 150 years ago. Approximately at the same time began import of various kinds of fruit cultivars from France and Germany (Slović, 1955). Nursery production was particularly developed and modernized after World War II. At the time there were established many research institutions, imported and created many vegetative rootstocks and cultivars. Production methods and quality control of fruit seedlings were at the level of developed countries, which created conditions for establishment of highly productive fruit nurseries (Medigović and Đaković, 2008).

In recent decades, nursery production has stagnated primarily because production in big scale nurseries has been abandoned due to political and economical transformation in Serbia. Instead, there were formed small family owned fruit tree nurseries. But such small nurseries are not able to provide all the conditions for modern production. Therefore, the fruit seedlings are of lower quality due to insufficient use of modern technology, poor quality control, impossibility of engaging highly qualified employees etc. According to statistics, in the period after 2013 the total area under all types of nurseries in Serbia (fruit, grape, forest and other nurseries) ranged between 1,200 and 1,600 hectares $^{5}$, with decreasing tendencies.

Very high investments are needed to renew old nurseries, to establish new once and to increased export of fruit seedlings. On the other hand, there have been no researches conducted in Serbia regarding economic effectiveness of investments in fruit seedlings production. Economic effects

\footnotetext{
${ }^{3}$ http://pod2.stat.gov.rs/ObjavljenePublikacije/G2016/pdf/G20162019.pdf

${ }^{4} \mathrm{http} / / /$ www.fao.org/faostat/en/\#data/EL

${ }^{5}$ http://pod2.stat.gov.rs/ObjavljenePublikacije/G2016/pdf/G20162019.pdf
} 
of nursery production in Serbia were analyzed only for production of forestry seedlings (Jakovčević, 2009). Gogić (2010) analyzed economic efficiency of investments in fruit production, but he did not separately analyzed investments in fruit tree nurseries. All other previous research in Serbia have been devoted to technical and technological aspects of fruit tree nurseries production (Zec et al., 2006; Nikolić et al., 2006; Keserović et al., 2003; Korać et al., 1995; Stanković and Jovanović, 1990; Medigović and Đaković, 2008).

There are also only few papers in the international journals dealing with economic issues of fruit tree nurseries. Research conducted in Malawi determined that even in conservative scenarios, investment in a fruit nursery can breakeven in only 1.5 years (Faulkner et al., 2009). The financial analysis of investments in simple nursery (temporary shade) and expensive nursery (net house irrigated by micro sprinklers) revealed that (in the conditions of Etiophia) higher NPV is achieved by investment in simple nursery than in more expensive one (Avihai and Workafes, 2011).

Akinnifesiet et al. (2007) determined that indigenous fruit tree nurseries in tropics were profitable having positive NPV and very high internal rate of return that ranged from 54\% to 58\% (depending on type of nursery). Economic analysis of fruit tree nurseries conducted in Albania (Cakalli, M., 2012) showed that all the nurseries studied are profitable. In terms of the best model of a nursery, farms producing two species of fruit trees are followed by those producing one species. They have better financial indicators than those producing three to four species.

Buyukarikan and Gul (2014) examined certified temperate climate fruit spices nurseries in Isparta province in Turkey. Authors examined various types of enterprises (mostly cooperatives) dealing mostly with production of apple seedlings and examine their production value, costs, profits and other economic and technical indicators. It is determined that the major problems for all nurseries are related to marketing, export and import. Similar conclusion is presented by Retamales (2011) for the entire fruit industry. In order to remain competitive, fruit industry has to overcome important challenges, such as climate change, issues related to labor, consumers expectations etc. Berhe et al. (2009) stated that fruit nursery operation is not an end by itself; rather it is a way to support the fruit industry so that benefits will not only be limited to the nursery operators but also to the broader fruit growers as well. Fruit productin could be very important for Serbian export to the EU because it is labor intensive activity. It is in accordance with results of research conducted by Lojanica (2016) who determined that the economy of the Republic of Serbia is competitive in exports in those sectors where laborintensive products dominate. Author determined that Serbian export on the EU market is competitive in some sectors, for example in food sector. 
Having all that in mind, the goal of this paper is to analyze economic efficiency of investments in fruit tree nurseries. Because there are various models for establishment and use of fruit tree nurseries, it is necessary to determine which model is economically more acceptable. It is also needed to analyze economic effectiveness of these investments in risky circumstances.

\section{MATERIALS AND METHODS}

In the paper are formed two models of investments in fruit tree nurseries. Models differ by different dynamics of nursery establishment and use. To evaluate economic effectiveness of investments in nurseries there were used following methods:

- Enterprise budgeting and determination of net cash flows,

- Discounting methods for investment evaluation - Net Present Value (NPV), Internal Rate of Return (IRR) and Payback Period.

- Sensitivity analysis and scenario analysis methods were used to evaluate investments in risky circumstances.

Models of establishment and use of fruit tree nurseries differ from each other regarding following main features:

Model I - Revenues from the nursery will occur evenly during entire period of its use.

Model II - Revenues from the nursery will not occur evenly during period of its use.

In the nursery (on an area of 10 hectares) will be conducted shifts of various fruit seedlings (raspberry seedlings as well as seedlings of other fruits) and field crops (soybeans), at a pre - determined plan (tables 1 and 2). These models are defined on the basis of technical, technological and organizational characteristics of establishing fruit tree nursery in Central Serbia.

Table 1. - Change in total area under fruit seedlings and soybean for Model I (ha)

\begin{tabular}{|l|c|c|c|c|c|c|c|c|c|c|}
\hline \multirow{2}{*}{ Production type (ha) } & \multicolumn{10}{|c|}{ Years of investment } \\
\cline { 2 - 13 } & $\mathbf{1}$ & $\mathbf{2}$ & $\mathbf{3}$ & $\mathbf{4}$ & $\mathbf{5}$ & $\mathbf{6}$ & $\mathbf{7}$ & $\mathbf{8}$ & $\mathbf{9}$ & $\mathbf{1 0}$ \\
\hline 1. Soybean & 9.5 & 7 & 5 & 5 & 5 & 5 & 5 & 5 & 5 & 5 \\
\hline 2. Raspberry seedlings & 0.5 & 1 & 1 & 1 & 1 & 1 & 1 & 1 & 1 & 1 \\
\hline 3. Seedlings of other fruits & - & 2 & 4 & 4 & 4 & 4 & 4 & 4 & 4 & 4 \\
\hline Total area (ha) & 10 & 10 & 10 & 10 & 10 & 10 & 10 & 10 & 10 & 10 \\
\hline
\end{tabular}

Source - Authors 
Table 2. - Change in total area under fruit seedlings and soybean for Model II (ha)

\begin{tabular}{|l|c|c|c|c|c|c|c|c|c|c|}
\hline \multirow{2}{*}{\multicolumn{1}{|c|}{ Production type (ha) }} & \multicolumn{10}{|c|}{ Years of investment } \\
\cline { 2 - 12 } & $\mathbf{1}$ & $\mathbf{2}$ & $\mathbf{3}$ & $\mathbf{4}$ & $\mathbf{5}$ & $\mathbf{6}$ & $\mathbf{7}$ & $\mathbf{8}$ & $\mathbf{9}$ & $\mathbf{1 0}$ \\
\hline 1. Soybean & 8 & - & 2 & 10 & 8 & - & 2 & 10 & 8 & - \\
\hline 2. Raspberry seedlings & 2 & 2 & - & - & 2 & 2 & - & - & 2 & 2 \\
\hline 3. Seedlings of other fruits & - & 8 & 8 & - & - & 8 & 8 & - & - & 8 \\
\hline \multicolumn{1}{|c|}{ Total area (ha) } & 10 & 10 & 10 & 10 & 10 & 10 & 10 & 10 & 10 & 10 \\
\hline
\end{tabular}

Source - Authors

\section{RESULTS AND DISCUSSION}

\section{Profitability of investments in expected circumstances}

Land necessary for this fruit tree nursery will be purchased in the market. In addition, there will be necessary to invest in appropriate buildings, machinery, other fixed assets for nursery production as well as in working assets. On the basis of initial investments, cash revenues and cash expenses, net cash flows are determined for both investment models (table 3 ).

Table 3. - Net cash flows for both investment models (EUR)

\begin{tabular}{|c|r|r|r|r|r|r|r|r|}
\hline \multirow{2}{*}{ Year } & \multicolumn{3}{|c|}{ Model I } & \multicolumn{4}{c|}{ Model II } \\
\cline { 2 - 10 } & $\begin{array}{c}\text { Cash } \\
\text { revenue }\end{array}$ & $\begin{array}{c}\text { Investmen } \\
\text { ts (initial } \\
\text { outlay) }\end{array}$ & $\begin{array}{c}\text { Cash } \\
\text { expenses }\end{array}$ & $\begin{array}{c}\text { Net cash } \\
\text { flow }\end{array}$ & $\begin{array}{c}\text { Cash } \\
\text { revenue }\end{array}$ & $\begin{array}{c}\text { Invest } \\
\text { ments } \\
\text { (initial } \\
\text { outlay) }\end{array}$ & $\begin{array}{c}\text { Cash } \\
\text { expenses }\end{array}$ & $\begin{array}{c}\text { Net cash } \\
\text { flow }\end{array}$ \\
\hline 0 & & 294,387 & & $-294,387$ & & 319,892 & & $-319,892$ \\
\hline 1 & 8,303 & 92,872 & 18,538 & $-103,107$ & 6,992 & 246,528 & 44,043 & $-283,579$ \\
\hline 2 & 66,118 & 76,884 & 71,881 & $-82,647$ & 120,000 & 105,762 & 226,411 & $-212,173$ \\
\hline 3 & 264,370 & 30,370 & 129,857 & 104,143 & 801,748 & 30,370 & 256,696 & 514,682 \\
\hline 4 & 264,370 & & 130,489 & 133,881 & 8,740 & & 5,707 & $-1,295$ \\
\hline 5 & 264,370 & & 131,255 & 133,115 & 6,992 & & 37,236 & $-37,051$ \\
\hline 6 & 264,370 & & 132,083 & 132,287 & 120,000 & & 213,853 & $-106,411$ \\
\hline 7 & 264,370 & & 132,390 & 131,980 & 801,748 & & 260,558 & 541,190 \\
\hline 8 & 264,370 & & 132,533 & 131,837 & 8,740 & & 8,827 & $-1,295$ \\
\hline 9 & 264,370 & & 132,533 & 131,837 & 6,992 & & 39,260 & $-37,051$ \\
\hline 10 & $652,063^{*}$ & & 132,533 & 519,530 & $715,732^{*}$ & & 214,692 & 489,321 \\
\hline Total & $2,577,074$ & 494,513 & $1,144,092$ & 938,469 & $2,597,684$ & 702,552 & $1,307,283$ & 546,446 \\
\hline
\end{tabular}

\section{Source - Authors}

Revenues in last year of production include revenues from fruit trees seedlings as well as salvage value of the investments (value of working assets as well as terminal value of fixed assets). To calculate indicators of economic effectiveness of investments in both types of nurseries (table 4) it is assumed that observed period (economic life of the projects) is 10 years. Discount rate 
used in this analysis is $8 \%$ and it is determined as weighted average cost of capital (WACC approach).

Table 4. - Indicators of economic effectiveness of investments in fruit trees nurseries

\begin{tabular}{|l|c|c|}
\hline $\begin{array}{c}\text { Indicators of economic effectiveness of } \\
\text { investments }\end{array}$ & Model I & Model II \\
\hline 1. Net present value & 349,155 EUR $>0$ & 74,172 EUR $>0$ \\
\hline 2. Internal rate of return & $18.18 \%>8 \%$ & $9.99 \%>8 \%$ \\
\hline 3. Payback period & 7.40 years $<10$ years & 9.67 years $<10$ years \\
\hline
\end{tabular}

Source - Authors

According to all indicators, both investment models are economically efficient - their NPV is positive, IRR is higher than discount rate, and payback period is shorter than economic life of the projects. Having in mind that these investments are mutually exclusive, Model I would be more acceptable because it provides higher NPV. Model I also has higher IRR and shorter payback period. This means that it is economically more efficient to produce standard quantity of seedlings during entire economic life of nursery (Model I). On the other hand significant variations of production (which are present in Model II) are less acceptable.

\section{Profitability of investments in risky circumstances}

Starting point for risk analysis will be data presented in table 3, which represents the most likely case regarding investments (initial cash outlays) and yearly cash flows. Economic effectiveness of investments in risky circumstances will be determined on the basis of their Net Present Values calculated using two methods:

- Sensitivity analysis (determines how NPV changes due to changes in only one important factor, while other factors are constant),

- Scenario analysis (which takes into account changes in a few factors that have the most significant influence on NPVs).

Sensitivity analysis takes into account some individual factors (in this example these factors are initial cash outlay, cash expenses and cash revenues). Changes in NPV of Model I caused by variations of individual factors are presented in table 5 and graph 1. It is noticeable that NPV of investment in Model $\mathrm{I}$ is the most sensitive regarding variations of cash revenues. It is less sensitive on variations of cash expenses, and the least sensitive regarding changes of investment (initial cash outlay). The same conclusion could be made for investment in Model II (table 5 and graph 2). 
STR 43-54

Table 5. - Changes in NPV depending on changes in individual factors (Model I) (000 EUR)

\begin{tabular}{lcccccccc}
\hline & \multicolumn{8}{c}{ Interval of change } \\
\cline { 2 - 8 } \multicolumn{1}{c}{ Factors which changes } & $\mathbf{7 0 . 0}$ & $\mathbf{8 0 . 0}$ & $\mathbf{9 0 . 0}$ & $\mathbf{1 0 0 . 0}$ & $\mathbf{1 1 0 . 0}$ & $\mathbf{1 2 0 . 0}$ & $\mathbf{1 3 0 . 0}$ \\
\hline $\begin{array}{l}\text { 1. Cash revenues } \\
\text { 2. Cash expenses }\end{array}$ & -60.9 & 75.8 & 212.5 & 349.2 & 485.8 & 622.5 & 759.2 \\
$\begin{array}{l}\text { 3. Investment (initial } \\
\text { outlay) }\end{array}$ & 436.4 & 407.3 & 378.2 & 349.2 & 320.1 & 291.0 & 261.9 \\
\hline
\end{tabular}

Source - Authors

Graph 1. - Changes in NPV of investment in Model I caused by variations of individual factors

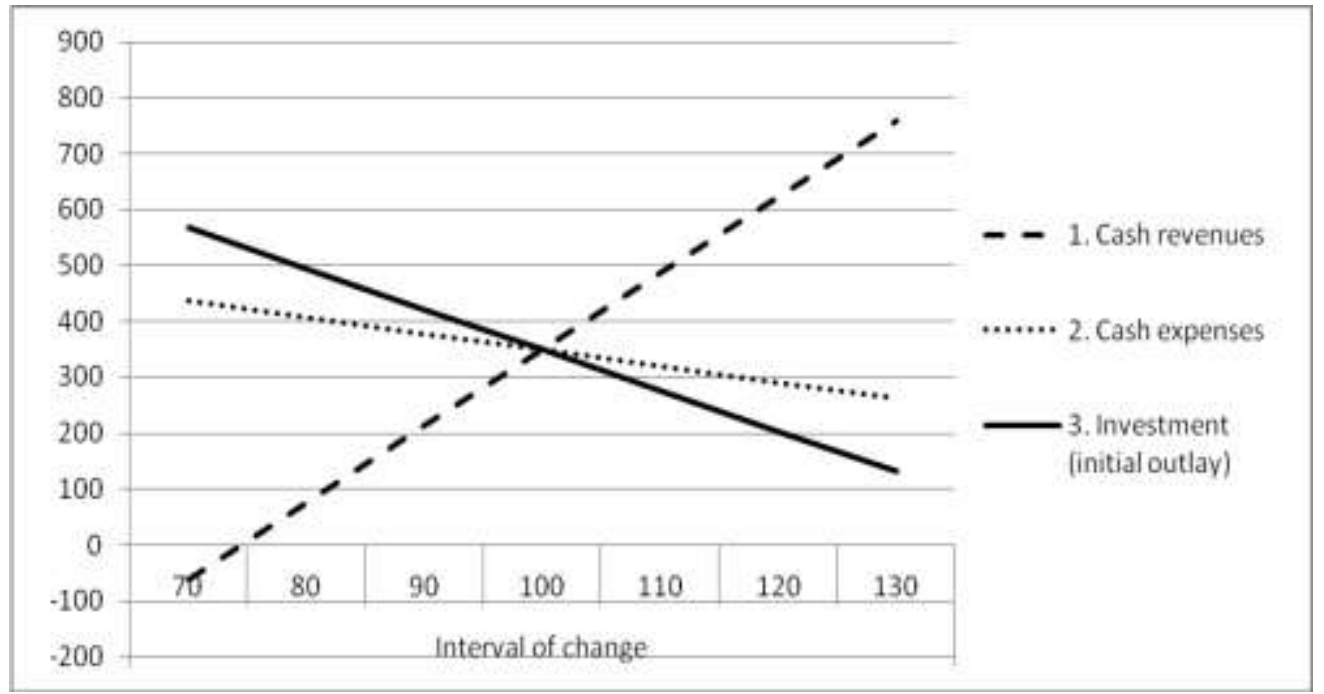

Source - Authors

Table 5. - Changes in NPV depending on changes in individual factors (Model II) (000 EUR)

\begin{tabular}{|c|c|c|c|c|c|c|c|}
\hline \multirow{2}{*}{ Factor which changes } & \multicolumn{7}{|c|}{ Interval of change } \\
\hline & 70.0 & 80.0 & 90.0 & 100.0 & 110.0 & 120.0 & 130.0 \\
\hline 1. Cash revenues & -310.9 & -174.5 & -38.0 & 98.4 & 234.8 & 371.2 & 507.6 \\
\hline 2. Cash expenses & 214.5 & 175.8 & 137.1 & 98.4 & 59.7 & 21.0 & -17.7 \\
\hline $\begin{array}{l}\text { 3. Investment (initial cash } \\
\text { outlay) }\end{array}$ & 362.0 & 274.1 & 186.3 & 98.4 & 10.5 & -77.4 & -165.3 \\
\hline
\end{tabular}

Source - Authors 
Graph 2. - Changes in NPV of investment in Model II caused by variations of individual factors

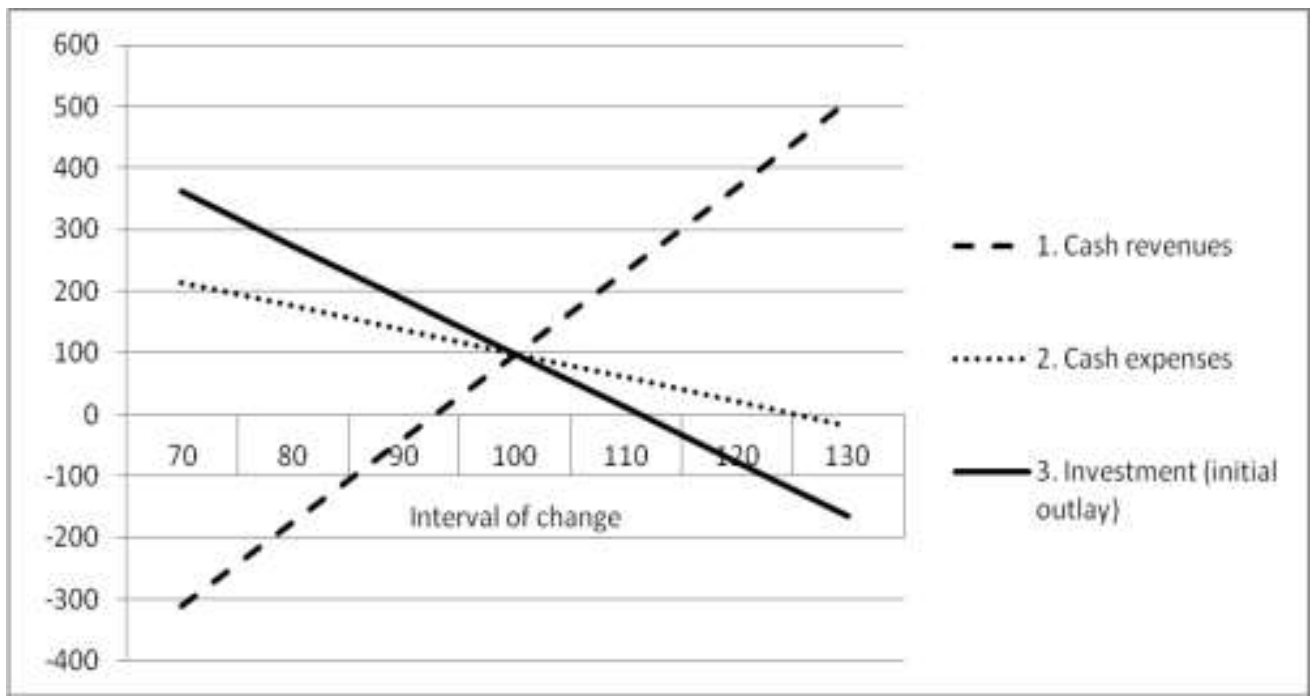

Source - Authors

It is possible to determine more precisely so called limitary (acceptable) deviation of certain factors within sensitivity analysis. If increase or decrease in one factor is higher than limitary (acceptable) deviation investment in fruit tree nursery will not be economically acceptable (table 6).

Table 6. - Acceptable deviations of the most important factors for Model I and Model II

\begin{tabular}{|c|c|c|c|c|}
\hline \multirow{2}{*}{ Factor which changes } & \multicolumn{2}{|c|}{$\begin{array}{c}\text { Acceptable decrease } \\
(\%)\end{array}$} & \multicolumn{2}{|c|}{$\begin{array}{c}\text { Acceptable increase } \\
(\%)\end{array}$} \\
\hline & Model I & Model II & Model I & Model II \\
\hline 1. Cash revenues & 25.54 & 7.21 & - & - \\
\hline 2. Cash expenses & - & - & $>30$ & 25.43 \\
\hline 3. Investment (initial cash outlay) & - & - & $>30$ & 11.19 \\
\hline
\end{tabular}

Source - Authors

Having in mind acceptable increases and decreases of certain factors it could be concluded that investment in Model II is more risky than investment in Model I.

Scenario analysis was performed according to methodology described by Peterson and Fabozzi (2002) and Brigham and Gapenski (1997). The analysis will start from three possible scenarios (best case, the most likely case and the worst case). The scenarios (table 7 and table 8) differ depending on expected economic conditions in fruit tree nursery production: 
- The most likely case represents average economic conditions in production of fruit seedlings, as well as average level of investments in establishing nurseries.

- Assumptions for the best case scenario comparing to the most likely case - cash revenues will increase by $5 \%$, cash expenses will decrease by $10 \%$, initial cash outlay (investment) will decrease by $15 \%$.

- Assumptions for the worst case scenario comparing to the most likely case - cash revenues will decrease by $10 \%$, cash expenses will increase by $15 \%$, initial cash outlay (investment) will increase by $20 \%$.

Table 7. - Expected NPV and indicators of risk for Model I

\begin{tabular}{|l|c|c|c|}
\hline \multicolumn{1}{|c|}{ Scenario } & NPV & $\begin{array}{c}\text { Probability of } \\
\text { outcome }\end{array}$ & Total (000 EUR) \\
\hline Best case & 533,8 & 0.25 & 133,4 \\
\hline Most likely case & 349,2 & 0.50 & 174,6 \\
\hline Worst case & 45,3 & 0.25 & 11,3 \\
\hline I Expected NPV & & 319,3 \\
\hline II Standard deviation of NPV & 175,3 \\
\hline III Coefficient of variation & & 0,55 \\
\hline
\end{tabular}

Source - Authors

Table 8. - Expected NPV and indicators of risk for Model II

\begin{tabular}{|l|c|c|c|}
\hline \multicolumn{1}{|c|}{ Scenario } & NPV & $\begin{array}{c}\text { Probability of } \\
\text { outcome }\end{array}$ & Total (000 EUR) \\
\hline Best case & 312,5 & 0.25 & 78,1 \\
\hline Most likely case & 74,2 & 0.50 & 37,1 \\
\hline Worst case & $-247,3$ & 0.25 & $-61,8$ \\
\hline I Expected NPV & & 53,4 \\
\hline II Standard deviation of NPV & 200,6 \\
\hline III Coefficient of variation & & 3,76 \\
\hline
\end{tabular}

Source - Authors

Expected NPV in both cases is positive, which means that in risky circumstances both analyzed models of investments in fruit tree nurseries are economically efficient. For both investment models expected NPVs are lower than NPVs in the most likely case. Coefficient of variation will be used to determine investment model which is less risky. This indicator is calculated by dividing standard deviation by expected net present value, and expresses risk of investment per unit of net present value. Coefficient of variation of investment Model I is 6.84 times lower than coefficient of variation of investment Model II. Therefore investment in Model I is considered to be more acceptable in risky business environment. The same conclusion could 
be made on the basis of two other indicators, because Model I has higher expected NPV and lower standard deviation than Model I.

\section{CONCLUSION}

There are very good conditions in Serbia for growing fruit. However, in the last two decades there has been stagnation in area under orchards and a slight increase in the volume of fruit production. Therefore, in order to increased areas of orchards, it is necessary to renew the existing and raise new fruit tree nurseries. Economic evaluation of investments in fruit tree nurseries was done on the models representing different dynamics of the establishment and use of the nurseries. The models were based on real technological, organizational and economic conditions in a fruit growing region of the Republic of Serbia. Using appropriate methods for economic evaluation of investments it was determined that both investment models are economically efficient. Nevertheless, investment which ensures uniform use of the land for getting seedlings is more economically acceptable (Model I).

Establishment and use of fruit tree nurseries is exposed to the influence of various factors which are hardly predictable. Because establishment of nursery requires very high investment funds, while making investment decisions it is needed to consider its economic efficiency in risky conditions. It was determined that in risky circumstances Model I is more favorable, which means less risky. It is also necessary to provide steady level of income, because investments are the most sensitive on its variation. Therefore investors in fruit tree seedlings production should be primarily concerned how to maintain production and market price of seedlings at certain level.

\section{REZIME \\ EKONOMSKA EFEKTIVNOST INVESTICIJA U RASADNIKE ZA PROIZVODNJU VOĆNIH SADNICA}

Da bi se razvila i unapredila voćarska proizvodnja u Srbiji neophodno je da se investira u zasnivanje rasadnika za proizvodnju kvalitetnih voćnih sadnica. Zbog toga je cilj ovog rada da se analizira ekonomska efektivnost investicija u rasadnike za proizvodnju sadnica voća. Da bi se utvrdila ekonomska efektivnost ovih investicija u očekivanim uslovima poslovanja korišćene su diskontne metode za ocenu investicija (neto sadašnja vrednost, interna stopa rentabilnosti i metoda roka povraćaja) dok su za ocenu investicija u uslovima rizika korišćene analiza osetljivosti i scenario analiza. Utvrđeno je da su investicije u rasadnike za proizvodnju sadnica voća ekonomski opravdane, 
čak i u rizičnim uslovima poslovanja. Investicija u tip rasadnika koji obezbeđuje uravnoteženije novčane tokove je ekonomski prihvatljivija i manje rizična.

Ključne reči: investicije, rasadnici, neto sadašnja vrednost, analiza osetljivosti, scenario analiza

\section{REFERENCES}

1. Avihai, I., \& Workafes, W. (2011). Fruit Tree Nurseries \& Plant Tissue Culture. USAID - MASHAV - MoA, Joint Technical Program. (sourcebook), page 14..

2. Buyukarikan, U., \& Gul, M. (2014). Economic analysis of certified nursery producing enterprises in temperate climate fruits: a case of Isparta Province. Custos e @gronegócio on line, Vol. 10, No. 4, 60-72.

3. Brigham, F.E., \& Gapenski, L.C. (1997). Financial Management Theory and Practice. The Dryden Press. Eight Edition.

4. Cakalli, M. (2012). Economic analysis of fruit tree nurseries in Albania. Agroznanje, 13(1), doi:10.7251/agren1201067c

5. Faulkner, L., Harrington, J., Levy, D., \& The, K. (2009). Commercial opportunities for fruit in Malawi. ICRAF Working paper, Nairobi, Kenya, no. 86.. doi:10.5716/wp16120.pdf

6. Gogić, P. (2010). Ekonomska efektivnost podizanja višegodisnjih zasada. Zemun: Poljoprivredni fakultet. Monografija.

7. Jakovčević, K. (2009). Utvrđivanje ekonomskih efekata proizvodnje sadnica četinara i lišćara. Ekonomika poljoprivrede,God. 56, br. 4, 601615.

8. Keserović, Z., Ružević, M., Mitrović, M., Nikolić, M., Gvozdenović, D., Oparnica, Č., \& Ružić, Đ.V. (2003). Proizvodnja sadnog materijala voćaka. Savremena poljoprivreda, Vol. 52, br. 1-2, 7-14.

9. Korać, M., Ranković, M., \& Jovanović, M. (1995). Vizija organizacije rasadničke proizvodnje u Jugoslaviji. Jugoslovensko voćarstvo, vol. 29, br. 109-110.

10. Medigović, J., \& Đaković, M. (2008). Proizvodnja sadnica voćaka. Beograd: Partenon.

11. Nikolić, M., Paunović, S., Ružić, Đ., Veličković, M., Keserović, Z., \& Mitrović, M. (2006). Rasadnička proizvodnja i agrotehnika voćaka. Voćarstvo, vol. 40, br. 153, 3-17.

12. Peterson, P.P., \& Fabozzi, F.J. (2002). Capital Budgeting: Theory and Practice. John Wiley \& Sons, Inc. 
13. Slović, D. (1955). Organizacija rasadnika i proizvodnja voćnih sadnica. Beograd: Zadružna knjiga.

14. Stanković, D., \& Jovanović, M. (1990). Opšte voćarstvo. Beograd: IRO "Građevinska knjiga".

15. Zec, G., Đurović, S., Čolić, S., \& Janković, Z. (2006). Proizvodnja kontejnerskih sadnica breskve i trešnje. Zbornik radova Instituta PKB Agroekonomik, vol. 12, br. 3, 58-63.

16. Akinnifesi, F.K., Leakey, R.B., Ajayi, O.C., Sileshi, G., Tchoundjeu, Z., Matacala, P., \& Kwesiga, F.R. (2007). Indigenous Fruit Trees in the Tropics: Domestication, Utilization and Commercialization. CABI. First edition.

17. Berhe, K., Dessalegn, Y., Baredo, Y., Teka, W., Hoekstra, D., \& Tegegne, A. (2009). Smallholder-based fruit seedling supply system for sustainable fruit production in Ethiopia: lessons from the IPMS experience. In Practical Action Conference, Nairobi, Kenya, September 21-25, 2009. Nairobi, Kenya: Practical Action East Africa.

18. Retamales, J.B. (2011). World temperate fruit production: characteristics and challenges. Revista Brasileira de Fruticultura, 33(spe1), 121-130. aboticabal - SP, Volume Especial, E.. doi:10.1590/s010029452011000500015

19. Lojanica, M.N. (2016). Konkurentnost srpskog izvoza na tržište Evropske unije. Poslovna ekonomija. Vol. XVIII, br. 1, 295-311.

Ovaj rad je primljen 15.10.2017., a na sastanku redakcije časopisa prihvaćen za štampu 09.01.2018. godine. 